\title{
Distal Bile Duct Cancer pNX TNM Finding v7
}

National Cancer Institute

\section{Source}

National Cancer Institute. Distal Bile Duct Cancer pNX TNM Finding v7. NCI Thesaurus.

Code C90254.

Distal bile duct cancer in which the regional lymph nodes cannot be assessed. (from AJCC 7th Ed.) 